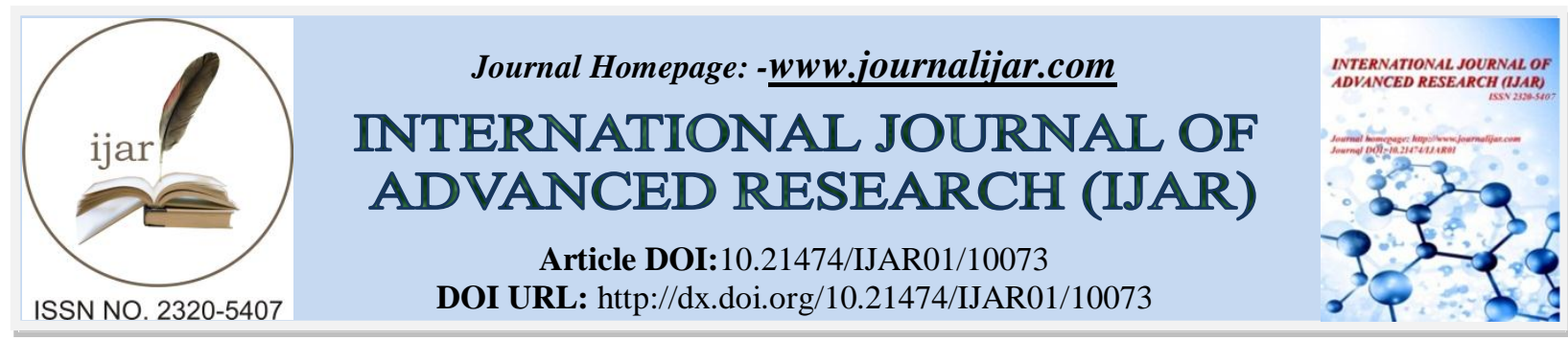

RESEARCH ARTICLE

\title{
EFFECTIVENESS OF YOGA ON BIO PHYSIOLOGICAL VARIABLES AMONG PATIENTS WITH HYPERTENSION: A PILOT REPORT.
}

\section{K. Chandralekha ${ }^{1}$, Dr. B. Sreelekha ${ }^{2}$ and Dr. J. Jasmin ${ }^{3}$.}

1. PhD Scholar, Meenakshi Academy of Higher Education and Research, Chennai.

2. HOD, Department of Medical and surgical Nursing, Faculty of Nursing, Sri Ramachandra University, Chennai.

3. Department of Medical and surgical Nursing, MTPGHS\&RI, Puducherry.

\section{Manuscript Info}

\section{Manuscript History}

Received: 12 September 2019

Final Accepted: 14 October 2019

Published: November 2019

Key words:-

Yoga, Biophysiological variable,

Hypertension.

\begin{abstract}
Hypertension is one among the leading contributor to burden of disease globally. A quantitative quasi experimental study was conducted to find the reliability and feasibility of tools and intervention with 20 samples selected through convenience sampling technique for study and control group in medical wards of SVMCHRC, Puducherry. The patients aged between 40-60 years, both gender diagnosed with hypertension were included as samples. Demographic and clinical data were collected by structured questionnaires. The biophysiological variables were assessed by using various scales such as modified American heart association blood pressure scale, modified American heart association resting heart rate scale, respiratory rate scale, the modified WHO BMI scale and modified Perceived Stress Scale by Sheldon Cohen. The yoga (specific yogasanas - Arthakati chakrasana, Ardha pavanmuktasana, Uttanpadasana and shavasana. Pranayama - Anulom viloma, Bhramari Pranayama and om meditation practice) was implemented to the study group. The patients were followed for twelve weeks. After that post test was conducted with same questionnaires and tools. The results revealed that the tools used, criteria for sample selection, the implementation of interventions were highly reliable and feasible for implementation.
\end{abstract}

Copy Right, IJAR, 2019,. All rights reserved.

\section{Introduction:-}

Hypertension is a "psychological classical silent killer" is the hallmark of various cardiovascular disorders mainly due to increase in the total peripheral resistance because of several etiological factors such as genetic factors, obesity, glucose intolerance, intake of high salt, cigarette smoking, heavy alcohol consumption, increased serum rennin levels. It is well recognized that hypertension is a major health problem in India. According to JNC hypertension is defined as systolic blood pressure as $140 \mathrm{~mm}$ of $\mathrm{Hg}$ or higher or diastolic blood pressure as $90 \mathrm{~mm}$ of $\mathrm{Hg}$ or higher or both. Whereas $<120 \mathrm{~mm}$ of $\mathrm{Hg}$ as SBP and $<80 \mathrm{~mm}$ of $\mathrm{Hg}$ as DBP is consider as the normal blood pressure.

\section{Statement of the Problem:-}

Assess the effectiveness of yoga on bio physiological variables among patients with hypertension in selected hospital at Puducherry. 


\section{Objectives:-}

To test the reliability, feasibility of the tool and effectiveness of yoga on bio physiological variable among patients with hypertension in selected hospital.

\section{Methodology:-}

Research Approach: - Quantitative research approach was used to evaluate the effectiveness yoga on bio physiological variables.

\section{Research Design: -}

Quasi Experimental Pretest - post test design was used for this study.

\section{Research Setting: -}

The study was conducted in the medical wards of Sri Venkateshwaraa Medical College Hospital and Research Centre.

\section{Population: -}

The population for the present study comprised of the patients with hypertension.

\section{Sample: -}

Samples includes the patients with hypertension who were admitted in male and female medical wards in SVMCH\&RC at Puducherry and who were fulfilling the inclusion criteria.

\section{Sample size: -}

The sample size is 200 as determined by power analysis. In that 100 samples selected for study group and 100 samples for control group. The pilot study was done with 20 samples.

\section{Sampling techniques: -}

Samples were selected by convenience sampling technique.

\section{Variables:-}

\section{Dependent Variable: -}

The dependent variable in this study is blood pressure among patients with hypertension.

\section{Independent Variable: -}

The independent variable in this study is yoga.

\section{Sampling criteria:-}

\section{Inclusion Criteria:-}

1. Both male and female patients with hypertension and aged between $40-60$ years.

2. Patients who have stage - 1 and stage - 2 hypertension.

3. Patients who could understand Tamil or English.

4. Patients who are willing to participate in this study.

5. Patients who were in treatment for more than one year and up to 10 years.

\section{Exclusion Criteria:-}

1. Patients those who were already practicing yoga, meditation and any other alternative therapy

2. Patients with severe anxiety and other co morbid condition like diabetes mellitus, heart disease, pulmonary, renal and any other systemic disease.

3. Patients who have the Blood pressure more than $180 / 110 \mathrm{~mm}$ of $\mathrm{Hg}$.

4. Patients with critical illness and uncooperative patients.

5. Patients who were in antenatal, postnatal and other gynecological problem like dysfunctional uterine bleeding and uterine prolapsed.

6. Patients who were having musculoskeletal condition or impairment like severe arthritis and osteoporosis. 


\section{Development and description of the tool:-}

\section{Part I: -}

Demographic Variables.

\section{Part II: -}

Clinical Variables.

\section{Part III: -}

Consists of tools to collect the biophysiological variables like blood pressure, heart rate, respiratory rate, body mass index and level of stress.

\section{Results and Discussion:-}

The reliability of the tools was assessed by inter-rater reliability and using Pearson correlation coefficient. The ' $r$ ' value obtained was 0.9 for the modified American heart association blood pressure scale, 0.9 for the modified American heart association resting heart rate scale, 0.8 for respiratory rate scale, 0.85 for the modified WHO BMI scale and 0.97 for modified Perceived Stress Scale by Sheldon Cohen. The correlation and coefficient values are very high and hence, these tools are reliable and enough for assessing effectiveness of yoga on bio physiological variables among patients with hypertension.

Table1:-Shows that the distribution of samples in study and control group based on demographic variables. Homogeneity was maintained between the study and control group. $\mathbf{n = 2 0}$

\begin{tabular}{|c|c|c|c|c|c|}
\hline \multirow[t]{2}{*}{ S.No } & \multirow[t]{2}{*}{ Demographic variables } & \multicolumn{2}{|c|}{ Study group } & \multicolumn{2}{|c|}{ Control group } \\
\hline & & $\mathbf{N}$ & $\%$ & $\mathbf{N}$ & $\%$ \\
\hline \multirow[t]{5}{*}{1.} & \multicolumn{5}{|l|}{ Age in years } \\
\hline & a. $40-45$ & 2 & 20 & 2 & 20 \\
\hline & b. $46-50$ & 3 & 30 & 2 & 20 \\
\hline & c. $51-55$ & 1 & 10 & 3 & 30 \\
\hline & d. $56-60$ & 4 & 40 & 3 & 30 \\
\hline \multirow[t]{4}{*}{2.} & \multicolumn{5}{|l|}{ Gender } \\
\hline & a. Male & 5 & 50 & 5 & 50 \\
\hline & b. Female & 5 & 50 & 5 & 50 \\
\hline & c. Transgender & 0 & 0 & 0 & 0 \\
\hline \multirow[t]{8}{*}{3.} & \multicolumn{5}{|l|}{ Educational status } \\
\hline & a. $\quad$ Professional & 0 & 0 & 0 & 0 \\
\hline & b. Graduate or Post graduate & 2 & 20 & 2 & 20 \\
\hline & c. Intermediate or Higher secondary & 2 & 20 & 3 & 30 \\
\hline & d. High school & 0 & 0 & 0 & 0 \\
\hline & e. $\quad$ Middle school & 1 & 10 & 0 & 0 \\
\hline & f. $\quad$ Primary school & 2 & 20 & 2 & 20 \\
\hline & g. No formal education & 3 & 30 & 3 & 30 \\
\hline \multirow[t]{8}{*}{4.} & \multicolumn{5}{|l|}{ Occupation } \\
\hline & a. $\quad$ Professional worker & 1 & 10 & 1 & 10 \\
\hline & b. $\quad$ Semi-professional worker & 1 & 10 & 0 & 0 \\
\hline & c. Clerical, shop owner, farmer & 2 & 20 & 3 & 30 \\
\hline & d. $\quad$ Skilled worker & 1 & 10 & 0 & 0 \\
\hline & e. Semi- skilled worker & 0 & 0 & 0 & 0 \\
\hline & f. $\quad$ Unskilled & 1 & 10 & 2 & 20 \\
\hline & g. Unemployed & 4 & 40 & 4 & 40 \\
\hline \multirow[t]{3}{*}{5.} & \multicolumn{5}{|l|}{ Marital status } \\
\hline & a. $\quad$ Married & 8 & 80 & 8 & 80 \\
\hline & b. Un married & 0 & 0 & 0 & 0 \\
\hline
\end{tabular}




\begin{tabular}{|c|c|c|c|c|c|}
\hline & c. Widow & 2 & 20 & 2 & 20 \\
\hline & d. Divorced & 0 & 0 & 0 & 0 \\
\hline \multirow[t]{6}{*}{6.} & Monthly income & & & & \\
\hline & a. $\quad$ Below Rs 5000 & 4 & 40 & 4 & 40 \\
\hline & b. $\quad$ Rs $5001-10,000$ & 1 & 10 & 1 & 10 \\
\hline & c. Rs $10,001-15,000$ & 2 & 20 & 3 & 30 \\
\hline & d. Rs $15,001-20,000$ & 1 & 10 & 1 & 10 \\
\hline & e. Above Rs 20,000 & 2 & 20 & 1 & 10 \\
\hline \multirow[t]{3}{*}{7.} & Place of living & & & & \\
\hline & a. Urban & 4 & 40 & 4 & 40 \\
\hline & b. $\quad$ Rural & 6 & 60 & 6 & 60 \\
\hline \multirow[t]{4}{*}{8.} & Types of family & & & & \\
\hline & a. Nuclear family & 5 & 50 & 4 & 40 \\
\hline & b. Joint family & 2 & 20 & 3 & 30 \\
\hline & c. Extended family & 3 & 30 & 3 & 30 \\
\hline \multirow[t]{5}{*}{9.} & Source of information abot & & & & \\
\hline & a. $\quad$ Professional & 6 & 60 & 6 & 60 \\
\hline & b. Mass media & 2 & 20 & 2 & 20 \\
\hline & c. $\quad$ Relatives & 2 & 20 & 2 & 20 \\
\hline & d. Friends & 0 & 0 & 0 & 0 \\
\hline \multirow[t]{3}{*}{10.} & Food pattern & & & & \\
\hline & a. Vegetarian & 2 & 20 & 2 & 20 \\
\hline & b. $\quad$ Mixed & 8 & 80 & 8 & 80 \\
\hline
\end{tabular}

Table 2:-Shows the distribution of samples in study and control group based on clinical variables. Homogeneity was maintained between the study and control group. $\mathbf{n}=\mathbf{2 0}$

\begin{tabular}{|c|c|c|c|c|c|}
\hline \multirow[t]{2}{*}{ S.No } & \multirow[t]{2}{*}{ Clinical variables } & \multicolumn{2}{|c|}{ Study group } & \multicolumn{2}{|c|}{ Control group } \\
\hline & & $\mathbf{N}$ & $\%$ & $\mathbf{N}$ & $\%$ \\
\hline \multirow[t]{6}{*}{1.} & \multicolumn{5}{|l|}{ History of exposure with any life events } \\
\hline & a. Any accident leading to physical injury & 0 & 0 & 0 & 0 \\
\hline & b. Difficult to adjust with working environment & 4 & 40 & 4 & 40 \\
\hline & c. $\quad$ Any Family conflicts & 0 & 0 & 0 & 0 \\
\hline & d. $\quad$ Sudden loss of employment & 2 & 20 & 1 & 10 \\
\hline & e. Nil & 4 & 40 & 5 & 50 \\
\hline \multirow[t]{8}{*}{2.} & \multicolumn{5}{|l|}{ Family history of hypertension } \\
\hline & a. yes & 5 & 50 & 4 & 40 \\
\hline & b. No & 5 & 50 & 6 & 60 \\
\hline & \multicolumn{5}{|l|}{ 1a.If yes, Specify the relationship } \\
\hline & a. Father & 2 & 20 & 2 & 20 \\
\hline & b. Mother & 2 & 20 & 1 & 10 \\
\hline & c. Grandparents & 1 & 10 & 1 & 10 \\
\hline & d. $\quad$ Nil & 5 & 50 & 6 & 60 \\
\hline \multirow[t]{4}{*}{3.} & \multicolumn{5}{|l|}{ Stages of Hypertension } \\
\hline & a. $\quad$ Pre hypertension & 0 & 0 & 0 & 0 \\
\hline & b. $\quad$ Stage-I & 8 & 80 & 9 & 90 \\
\hline & c. $\quad$ Stage - II & 2 & 20 & 1 & 10 \\
\hline 4. & \multicolumn{5}{|l|}{ Duration of Hypertension } \\
\hline & $1-3$ years & 2 & 20 & 2 & 20 \\
\hline & 4-6years & 4 & 40 & 4 & 40 \\
\hline
\end{tabular}




\begin{tabular}{|c|c|c|c|c|c|}
\hline & $7-9$ years & 3 & 30 & 3 & 30 \\
\hline & $10 \&$ more than 10 years & 1 & 10 & 1 & 10 \\
\hline 5. & \multicolumn{5}{|l|}{ Treatment duration } \\
\hline & $1-3$ years & 2 & 20 & 2 & 20 \\
\hline & 4-6years & 4 & 40 & 4 & 40 \\
\hline & $7-9$ years & 3 & 30 & 3 & 30 \\
\hline & $10 \&$ more than 10 years & 1 & 10 & 1 & 10 \\
\hline 6. & \multicolumn{5}{|c|}{ History of hospitalization for hypertension treatment. } \\
\hline & a. $\quad$ Yes & 7 & 70 & 6 & 60 \\
\hline & b. $\quad$ No & 3 & 30 & 4 & 40 \\
\hline 7. & \multicolumn{5}{|l|}{ Medication compliance } \\
\hline & $\begin{array}{ll}\text { a. } & \text { Regularly } \\
\end{array}$ & 3 & 30 & 3 & 30 \\
\hline & b. Only when symptoms arise & 1 & 10 & 1 & 10 \\
\hline & c. Irregular & 5 & 50 & 4 & 40 \\
\hline & d. $\quad$ No follow up & 1 & 10 & 2 & 20 \\
\hline 8. & \multicolumn{5}{|l|}{ Taking any drug for treatment } \\
\hline & a. Amlodipine & 6 & 60 & 6 & 60 \\
\hline & b. $\quad$ Atenolol & 2 & 20 & 2 & 20 \\
\hline & c. Propronalal & 1 & 10 & 1 & 10 \\
\hline & d. $\quad$ Others & 1 & 10 & 1 & 10 \\
\hline & \multicolumn{5}{|c|}{ 17.a. If yes specify the duration of drug intake } \\
\hline & a. $\quad$ Once a day(OD) & 6 & 60 & 7 & 70 \\
\hline & b. $\quad$ Two times a day(BD) & 4 & 40 & 3 & 30 \\
\hline & $\begin{array}{ll}\text { c. } & \text { Three times a day(TDS) } \\
\end{array}$ & 0 & 0 & 0 & 0 \\
\hline 9. & \multicolumn{5}{|c|}{ Type of exercise is followed by the patient } \\
\hline & a. Vigorous exercises & 2 & 20 & 0 & 0 \\
\hline & b. $\quad$ Daily swimming & 1 & 10 & 2 & 20 \\
\hline & Yoga and meditation & 0 & 0 & 0 & 0 \\
\hline & d. Daily walking & 2 & 20 & 3 & 30 \\
\hline & e. Anyother & 5 & 50 & 5 & 50 \\
\hline 10. & \multicolumn{5}{|l|}{ Habits } \\
\hline & a. Alcohol & 1 & 10 & 1 & 10 \\
\hline & b. $\quad$ Smoking & 1 & 10 & 0 & 0 \\
\hline & c. Tobacco chewing & 1 & 10 & 1 & 10 \\
\hline & d. $\quad$ All the above & 3 & 30 & 3 & 30 \\
\hline & None & 4 & 40 & 5 & 50 \\
\hline 11. & \multicolumn{5}{|l|}{ Experience of physical symptoms } \\
\hline & a. Daily & 1 & 10 & 1 & 10 \\
\hline & b. When medication is not taken & 3 & 30 & 4 & 40 \\
\hline & c. $\quad$ During any activities & 6 & 60 & 4 & 40 \\
\hline & d. $\quad$ Never experience & 0 & 0 & 1 & 10 \\
\hline
\end{tabular}

Table No 3:-Frequency and Percentage distribution of pre test and post test level of blood pressure in the study group. $(\mathbf{n}=\mathbf{2 0})$

\begin{tabular}{|l|c|c|c|c|}
\hline \multirow{2}{*}{ Blood pressure } & \multicolumn{2}{|c|}{ Pre test } & \multicolumn{2}{c|}{ Post test } \\
\cline { 2 - 5 } & & $\mathbf{N}$ & $\mathbf{\%}$ & $\mathbf{N}$ \\
\hline Normal blood pressure & 0 & 0 & 2 & 20 \\
\hline Pre hypertension & 0 & 0 & 4 & 40 \\
\hline Stage -1 & 8 & 80 & 4 & 40 \\
\hline
\end{tabular}




\begin{tabular}{|l|l|l|l|l|}
\hline Stage -2 & 2 & 20 & 0 & 0 \\
\hline
\end{tabular}

Table No 4:-Frequency and Percentage distribution of pre test and post test level of blood pressure in the control group. $(\mathbf{n}=\mathbf{2 0})$

\begin{tabular}{|l|c|c|c|c|}
\hline \multirow{2}{*}{ Blood pressure } & \multicolumn{2}{|c|}{ Pre test } & \multicolumn{2}{c|}{ Post test } \\
\cline { 2 - 5 } & $\mathbf{N}$ & $\mathbf{\%}$ & $\mathbf{N}$ & $\mathbf{\%}$ \\
\hline Normal blood pressure & 0 & 0 & 0 & 0 \\
\hline Pre hypertension & 0 & 0 & 3 & 30 \\
\hline Stage -1 & 9 & 90 & 6 & 60 \\
\hline Stage -2 & 1 & 10 & 1 & 10 \\
\hline
\end{tabular}

Table No 5:- Comparison of post-test level of systolic blood pressure between the study and control group.

\begin{tabular}{|c|c|c|c|}
\hline Post test & Mean & SD & $\begin{array}{c}\text { Unpaired t } \\
\text { test }\end{array}$ \\
\hline Study Group & 112 & 3.56 & $\mathbf{t}=\mathbf{5 . 2 2}$ \\
\hline Control Group & 135.2 & 3.68 & \\
\hline
\end{tabular}

This table showed that yoga was effective on reduction of systolic blood pressure among patients with hypertension.

Table No 6:- Comparison of post-test level of diastolic blood pressure between the study and control group.

\begin{tabular}{|c|c|c|c|}
\hline Post test & Mean & SD & Unpaired t test \\
\hline Study Group & 78 & 4.0 & $\mathbf{t}=\mathbf{2 . 6}$ \\
\hline Control Group & 83 & 4.58 & \\
\hline
\end{tabular}

This table showed that yoga was effective on reduction of diastolic blood pressure among patients with hypertension.

Table No 7:- Reliability of tools.

\begin{tabular}{|l|c|c|}
\hline \multicolumn{1}{|c|}{ Tool } & Mean & r value \\
\hline Blood pressure & 90 & 0.9 \\
\hline Heart rate & 90 & 0.9 \\
\hline Respiratory rate & 80 & 0.8 \\
\hline Body mass index & 85 & 0.85 \\
\hline Stress & 75 & 0.97 \\
\hline
\end{tabular}

\section{Discussion:-}

The main focus of this study was to test the reliability and feasibility of the data collection tools and intervention and its acceptability and effectiveness on reduction of blood pressure among patients with hypertension. The results indicated that tools used were highly reliable. The pilot study also showed that the sampling technique, inclusion and exclusion criteria were appropriate for sample selection. The method of administering the yoga and teaching methods selected and the proposed analytical measures were suitable for this study. The comparison between the groups showed that there was a statistical significance. The overall plan was effective, feasible and practicable to be applied in the main study.

\section{Conclusion:-}

The pilot study on the effectiveness of yoga on biophysiological variables among patients with hypertension as an evaluative method revealed that the data collection tools used was reliable, feasible and appropriate to be applied to the samples in the main study and the yoga was effective on reduction of blood pressure among patients with hypertension.

\section{Reference:-}

1. Brunner \& suddarth, "text book of Medical Surgical Nursing" $11^{\text {th }}$ edition. Phladelphia Lippincott publication, 2008. 
2. Bhavanani AB, Zeena S, Madanmohan M. Immediate Effect of Sukha Pranayama on Cardiovascular Variables in Patients of Hypertension. International Journal Of Yoga Therapy. 2011.

3. Salome Phelamei. World Health Day, Hypertension, High blood pressure, Cardiovascular diseases, Stroke, Heart Attack, CVD, World Health Organisation. 